\title{
Challenges in Teaching English to Young Learners at Primary Stage: A Case Study of the Primary Schools in the State of Kuwait
}

\author{
Hussain Al-Ali \\ Department of Teaching English to Speakers of Other Languages (TESOL) MA, Faculty of Education and Society, The University of Sunderland, \\ Sunderland City, UK \\ Katy Mann* \\ Department of Teaching English to Speakers of Other Languages (TESOL) MA Katy Mann Faculty of Education and Society, The University of \\ Sunderland, Sunderland City, UK
}

\begin{abstract}
The aim of this research paper is to identify the perceptions of teachers of the English language about the main challenges in teaching primary stage pupils and to recognize the challenges that are experienced locally in the five educational areas available in the state of Kuwait. Both qualitative and quantitative methods have been applied because data were supposed to be in the form of numbers. The survey was provided by a hard copy to about (20) teachers of English language in the state of Kuwait. The survey itself consisted of two sections. The first section referred to some sort of a ranking question. That means the teachers ordered the factors that might develop teaching English to young learners according to their point of views. The second section of the survey included an open question as follows: Which aspect do you think the most challenging in teaching young pupils and why? The results revealed that teachers of English are challenged by several factors including lack of training, resources, and knowledge. Most teachers suffered from lack of time to teach; particularly, teaching writing and grammar.

Keywords: Local challenges; Young learners; Teaching English; Discipline; Motivation; Differentiation; Grammar; Speaking; Writing; The class size.

(9) (1) CC BY: Creative Commons Attribution License 4.0

\section{Introduction}

Teaching means outcome of teachers' perception. The way of how learners understand is mainly the crucial point of the philosophy of teaching itself. That also revoloves around the most suitable ways of teaching learners as well as the appropriate practices those are to be applied in the classroom. Teaching also means the way of how one teacher develops his or her skills and abilities in specific areas. Encouraging learners, controlling in classroom and planning all refer to teachers maxims that function as rules for better behaviour. Teaching English is always required to be explored in teachers' perceptions so it is quite important to avoid mechanical teaching or reutilization without even thinking of how important is what is being taught to pupils in the classroom so that teachers of English can develop their educational experiences and standards.

Teachers' belief structure is not complicated since it is multi faced and interconnected. What is really considered as the most effective in teachers' beliefs on teaching English to young learners is behaviour and practice that are both ultimately related to their thinking and information process. So the ultimate work that is done by the teacher in the classroom is his or her beliefs whether there is awareness of philosophy of teaching English or not. However, teachers' beliefs are so necessary to the process of teaching and teachers should be familiar with their own philosophers, theories and beliefs. Their personal reflection ought to be always recorded so that they can be able to understand how these beliefs and philosophies impact their classroom practices. However, teaching English is not supposed to handle any obstacles so that all young learners can learn English very well and in an effective ways' particularly, during the the elementary stage that is considered as one of the most stage the learner passes through towards he next stages in his educational life.
\end{abstract}

\section{The Research Questions}

The research paper is to respond to two questions: 1) what are the perceptions of teachers of English language about the main challenges in teaching primary stage pupils in the state of Kuwait? 2) What challenges are experienced locally in the five educational areas available in the state of Kuwait?

\section{Theoretical Significance}

Some pressing challenges have been identified by the literature on teaching English to primary stage pupils. One basic challenge indicates that English as a subject is a compulsory one at the primary stage without any appropriate consideration who will teach it. Consequently, teachers may find themselves teach English to young learners without at least any training courses or adequate experience ( $\mathrm{Hu}, 2007)$.

Pedagogy is also another basic challenge to teachers of English language whether such pedagogy includes appropriate skills to all different levels of young learners or not (Kunnan, 2005). 
So the research papers aims to recognise the obstacles and challenges teachers of primary English language may encounter across a number of educational areas available in the state of Kuwait. The research paper is also to identify the variation and the expected causes for such a variation locally.

\section{Literature Review}

One of the most basic development policies in education is to develop teaching English in the primary stage that is considered as the main basis of the coming stages (Johnstone, 2009). It is also because the the most widespread language used in the whole world is English. Hu (2007), and Nunan (2003), argued that the significance of teaching English for young learners is supported by so many researchers in all parts of the world because of several reasons. Firstly, it is very necessary to begin teaching English from the early years. Secondly, the common use of English leads to a great economic globalization. Therefore, a huge number of governments began to support the idea of having English using beside the first language. Thirdly, it is higly prefered that children begin learning English in so that they can learn any new technologies in any field they may be intereseted in the future. As a result, most governments do not mind to introduce English to young learners freely in so many countries around the world.

As a global lingua franca, there has been frequently criticism of the English growth. Coleman (2011), challenged understanding of English popularity and status. Discussion revokes question about the premises in which teaching English for young learners; particularly, during the primary stage are predicted. Kumaravadivelu (2011) is greatly agree on Western approaches adoption to learning English language that helps in spreading English but he argued thay such a process may get England and the United States continue to benefit from such a widespread use of English politically and economocically. To fulfill the tasks of teaching young learners must be the mission of teachers around the world but this requires using pedagogic approach that must be suitable to pupils learning English (Pillar and Cho, 2013).

A number of challenges have been identified by the literature on teaching young learners English language; particularly, from the beginning. One of such challenge relates to the trend that believes that the pupils must study English at any cost; specially, in the elementary stage without any taking care of who is going to teach those young learners. What is really a serious problem is that there is a large number of foreign instructors of English who are not actually qualified to teach English in so many primary schools around as reported by the International Bank either because of the lack of training courses or because some teachers graduated from weak or unauthonticated universities or colleges (Nunan, 2003).

So many teachers may find themselves teach English without even teaching aids as in rural and poor countries in which the curriculum itself is impacted by the policy decisions. Young learners need communication skills on basic knowledge of English as a lingua franca. Therefore, most curriculum of young learners began to emphasize the competence of communication that; consequently, led to (CLT) that actually stands for linguistics communicative language teaching that is applied in some Asian countries and some areas in the Middle East (Ahn, 2011).

However, teachers of English may find it is highly difficult to deal effectively with any new approaches for many courses. One of these causes is that so many teachers may see (CLT) as an approach that is can be just applied in western countries not only to young learners but also to adults within small groups rather than big ones as in poor countries. So (CLT); as a result, would not be appropriate for those young learners who use English as a second language. Moreover, poor countire suffer from limited resources such as linguistics labs and teaching aids (Littlewood, 2007).

Teachers of English may just receive a basic physical training that get them struggle to apply CLT effectively in classrooms. Pedagogy also has to do with selecting appropriate resources. Text books that are prescribed in some countries but teachers in other countries is allowed to select approved books as in China and Singapore (Mee, 2003). However, many countries have not got appropriate text books to teach young learners English in classrooms (Mathew and Pani, 2009).

The lack of facilities in primary schools is the main problem faced by teachers of English as well as insufficient funds for such facilities as in South Korea. İnal (2009), argued the teachers of English in the primary stage are not always able to access to the technology benefits to enhance English teaching during the recent years. The lack of confidence as well as the law professional level of teachers of English is both another challenges for teaching English in the primary schools (Baker, 2008). CLT requires; as many teachers believe, special procedures in classrooms including teaching English in a target language that may lead to tension and anxiety among teachers of English in regard with their competence levels in various English basic skills (Kuchah, 2009).

Teachers of English believe that crowded and big classes are a common issue to young learners. So they believe it is impossible to apply CLT in such large classes in the light of the absence of appropriate curriculum that may support the idea of CLT itself at least. CLT needs pairwork and group work to be a successful way but such an approach can not be applied in large and crwoded classrooms. Teachers of English do not prefer any type of noise when they teach young learners various activities of speaking (Carless, 2004). It is quite difficult to motivate young people's because they may find difficulties in learning English relevance as they do not usually listen to or even speak with native speaker as in the Middle East area (Hu, 2007).

Examinations are not supported by appropriate curriculum or government policies in so many countries. These examinations focus on just vocabulary and grammar rather than speaking and other skills of English including listening, writing and reading (Kunnan, 2005). In most cases, young learners may look to their teachers as just mediators who are jutsreponsible for correcting answers and giving marks. Yet young learners are not encouraged to do things independently and this will not help to make them more relaxed and more ready to give answers by themselves (Ahn, 2011). 
Another common challenge is that English is not used widely among young learners. They are supposed to use English all the time until the end of the class rather than their own native language. Most teachers do not even tend to use English; meaning that they do not at least ask young pupils simple such as" Does anyone have any question"? Young learners are supposed to be punished when they begin or try to use their first language during the English classes by their own teachers. They must guide their young learners by allocating some sort of penalty system that has not to do with punishment. For example, a young learner has to recite a poem in front of the class when he or she might be caught using his or her on first language rather than English (Cameron, 2003).

Teachers of English may find their young learners hijack the class; meaning that that the lessons do not go where teachers of English want them to be. As a result, not all activities will be covered. On or two spoiled pupils may damage a whole classroom by noisy and the rest of pupils may got lost when teachers of English generally miscontrol the classroom. This proves young learners do not care of wasting any class and as long as they are not interacting or participating in English, the class will not be a productive experience at all if the lessons stay too far from the main topics. Therefore, it is very necessary to teachers of English to fix such a terrible problem by diverting conversation or by any urgent or successful way (Butler, 2004).

\section{Research Methodology}

A constructivist approach is so suitable in such a research paper because it is has to with teaching where everyone in the learning environment is the bearer of knowledge; teachers are concerned with process. Both qualitative and quantitative methods have been applied because data are supposed to be in the form of numbers (quantitative method) and words (qualitative method) (Punch, 2016).

The survey helped in giving local results across the targeted educational areas that are available in the state of Kuwait and uncovering the basic challenges in teaching English to young leraners according to the reponses of teachers of English who will answer the survey. The variation in challenges was illustrated by the qualitative data.

So an approach of mixed methods was applied for the current research paper. Such approach joins both qualitative and quantitative elements including point of views, data collection and analysis that helps in deep understanding and corroboration (Johnstone, 2009).

The mixed methods help also in allowing for a reference framework that acknowledges the man serious issues related to teaching English for young learners. The variation in challenge was illustrated by the qualitative data. The survey was provided via hard copy to the research sample that was the instructors of English in elementary schools in the state of Kuwait. Consequently, a standardized and efficient manner was created since the survey covered diverse data. The disadvantages of sampling require to be identified. Reis and Judd (2000), argues that the survey can reflect practices that need to be reported but cannot be represented since there may not be enough responses across the locations where the respondents live. Standard ratio of respondents is not provided by such type of sampling. However, opportunistic sampling can be fit to the objective of giving illustrations of the research samples viewpoints.

Hoque (2009), refers to several issues that are taken from the literature review inlcuding more access to better technologies on teaching, smaller rather than bigger and crowded classes and so on. The responses were descriptively analysed later on. Secondly, the question which was" What are the most challenges you face in your job as a teacher of English?. Such a question appealed so many responses. The answers were collected with correcting any spelling mistakes using Microsoft office 2003. A number of keywords variable class including grammar, discipline and motivation were referred to. Other categories were identified by looking for the remaining data. Each challenge that was recognised was classified separately but all items were considered despite of some categories with a very small number including appreciation and school activities. The statements were carefully examined. Results were statistical significance by a Chi square test. Therefore, the measures did not happened by accident. The teachers of English who completed the survey were the source of interviews and observations. Yes we'll be ok in all 5 educational areas available and the state of Kuwait. Areas where selected to include basic schools so as to provide explainations from various sides.

The results were then joined with the answers of survey and classified for each school to produce five different accounts. For the research paper purpose, separate accounts were regarded as a case study. In all five targeted educational areas, instant methodology was applied. Firstly, teachers of English were approached because did not mind be observed. After that, they were asked to be in an interview for gaining some information on the pupils' classes, the lesson plan and other information related to the observation and interview including classroom materials and documents of syllabus and policy. At least one teacherwas observed in each school available in each educational area in the state of Kuwait.

The observation processes relied on an audio recording. Notes were written down. Further interviews were conducted after the observation via transcripts. The findings from both open and closed questions were filtered in order to analyse the research paper data. Finally, the fieldnotes and the transcripts of interview were examined in order to recognise the challenges the teachers of English encounter in the state of Kuwait. Regardering the demographic information of respondents, most of them are males who are working in primary schools in the state of Kuwait in all targeted educational areas. Most respondents are around 35 years old while just over a quarter of them are around 25 years old and the rest are above 40 years old. Most of them have been also teaching young learners for more than five years. Regarding the level of education, most respondents have at least bachelor's degree in English. 


\section{Data Collection}

The survey was provided by a hard copy to about (20) teachers of English language in the state of Kuwait. The survey itself consisted of two sections. The first section refers to some sort of a ranking question. That means the teachers ordered the factors that may develop teaching English to young learners according to their point of views. The second section of the survey included an open question as follows: Which aspect do you think the most challenging in teaching young pupils and why? Such an open question helped so much in attracting more responses from the sample itself for just an analysis reason. The answers collected and the spelling mistakes were then corrected by using Word 2003. The most key words that relate to the challenges were then identified. Furthermore, interviews and observation process with (20) teachers, who completed the survey took place in the five educational areas available in the state of Kuwait. The participants were asked for some information such as the class, pupils, lessons plan, materials and so on. The researcher observed at least one lesson that was recorded for an analysis purpose.

\section{Data Analyse}

The survey outcomes were filtered by each educational area available in the state of Kuwait in oreder to identify the local challenges in order to analyse the data. Then, transcripts and filednotes were evaluated to identify the issues encountered by research sample i.e the targeted (20) teachers who belong to the five educational areas in Kuwait.

\section{The Practical Significance of the Research}

The research paper is very useful to future researchers, students and other TESOL professionals; particularly, in the Middle East area since the research papers may clarify to all education officials about one of the most basic issues which refer to the challenges that the teahers of English in the primary stage may face. Any researcher in such a field can build the results of the current research papers and conduct more elaborated studies to include; for example, higher stages such as intermediate and secondary ones. The recommendations that comes eventually may be also useful to TESOL professionals to help them finding out what are the main weak points in the field of teaching English and finding out the solutions and recommendation that may overcome all the challenges and positively influence the level of the academic achievement of students then.

For keeping participants' identities and personal data confidential and secure during the research, the researcher first gave the participants a consent form and information as well as a form of sample participant information to get them aware of what is going on. Then the materials were stored securely; no body could use or see them except the researcher who kept all information and data on his own labtop so that no one can see them. The researcher also avoided on-line questionnaires and prefer using a hard copy in which no names or any other private information of participants could be shown.

\subsection{Perceptions of Challenges by the Teachers of English in the State of Kuwait}

To answer the research question, a number of ranking questions has been answered by the respondents as shown in the following figure:

Figure-1. Factors ranking that would develop process of learning and teaching English in Kuwait

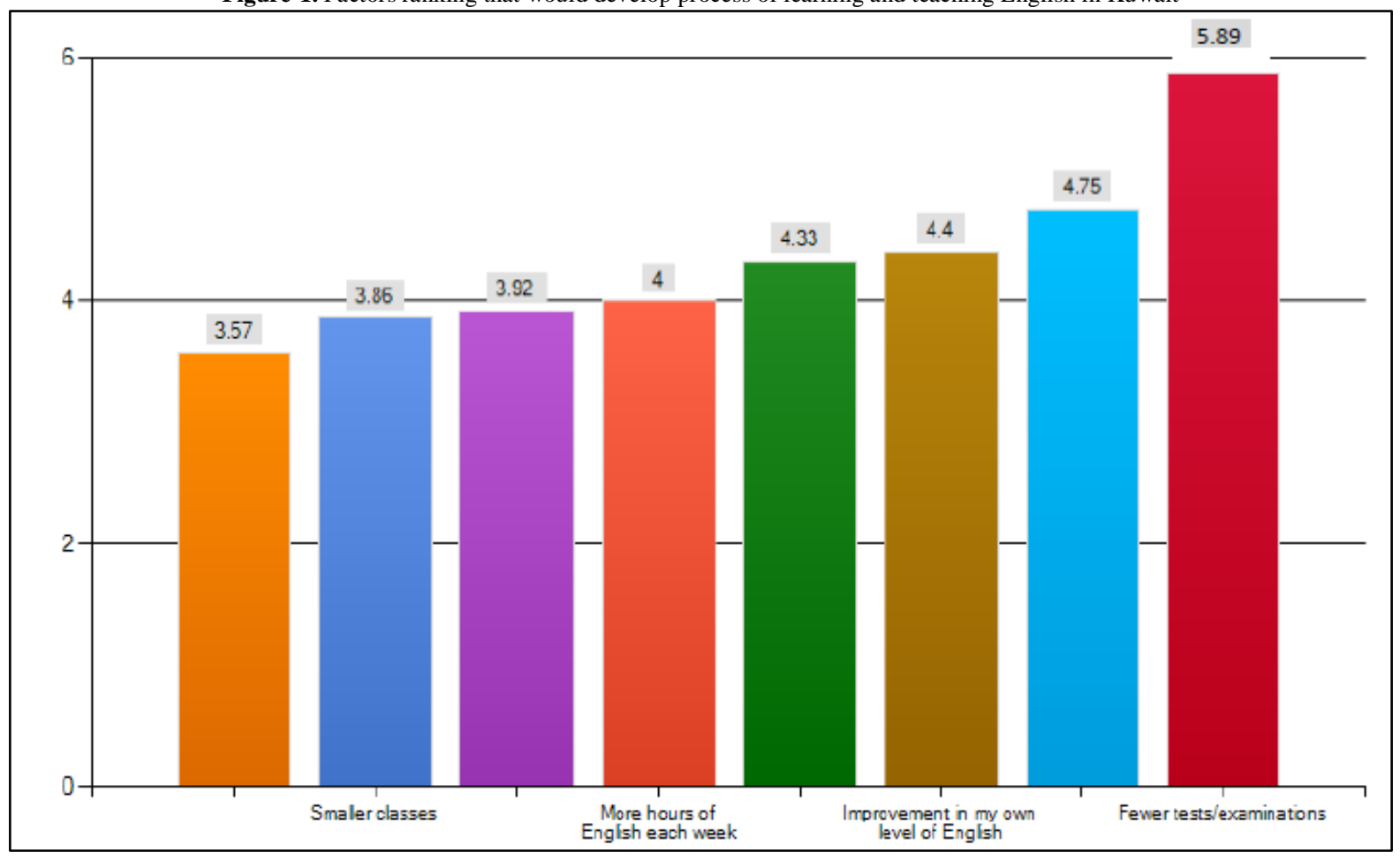


It is clear that the columns on the right are more necessary than those on the left. Less exams/ tests factor is the most significant factor in developming learning process and teaching English according to the respondents' answers. Beginning English from early stage is the next necessary factor. What may motivate a similar number of responses is accessing to resources in levels of English despite their less significance than other factors. One of the most globally factors is to learn new methods of English teaching. Moreover, more hours of English teaching, smaller size of classes, more access to resources and technologies are all always of attracting a large number of teachers. Such necessary outcomes will be deeply discussed below. The second Research question "Which aspect/ factor do you believe the most challenging in your job as a teacher of English? allowed more detailed information as seen in the following figure:

Figure-2. The challenges thare were identified by the teachers of English in the primary stage in Kuwait

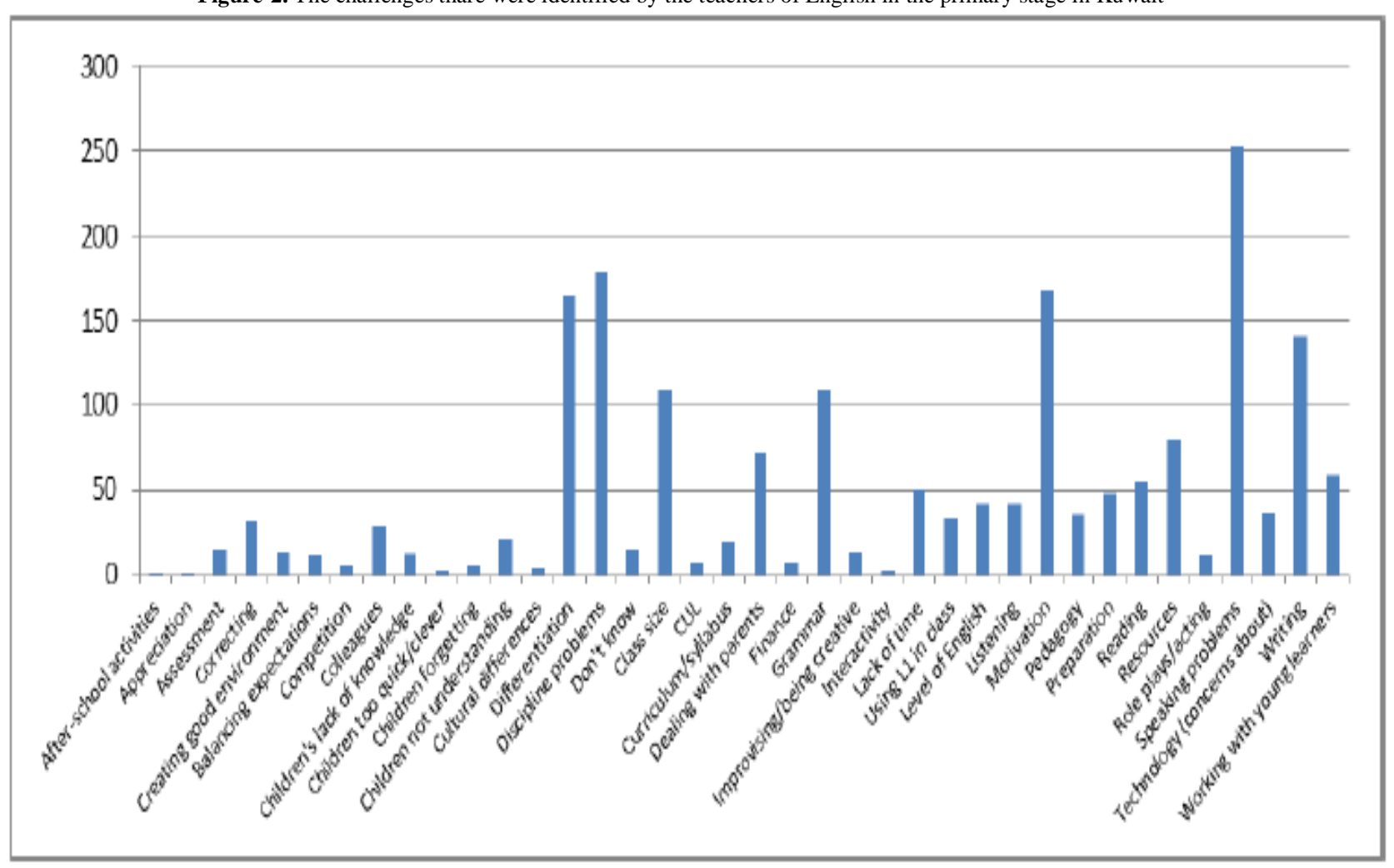

According to the results that mentioned in the above figure, the challenge that attracted the most comments was the problems of speaking was about (32) comments. Next, the problem of disciplines, behaviours, managing the classroom by the teacher, motivation, levels and abilities, disabled learners, students needs and teaching writing; particularly, in grade 4 and 5 in which pupils are supposed to write a small paragraph on a specific topic with provided helping words.

\subsection{Speaking}

Teaching speaking by teachers was the first basic challenge. As a classroom observation processes, such a result is surprising since teachers find difficulties with such an important skill. Several studies such as Baker (2008), and Littlewood (2007), identified the level of English of teachers as well as methods of teaching English as being problematic but these research papers did not identify speaking as a big challenge until nowadays. However, the way to get pupils to speak is considered as one of the most familiar comments. For instance, teachers can get and persuade their pupils to use English can be something they are able to do one day. So many pupils may hesitate to speak English in the classroom. It could be a threat or horror for them. So it is quite important to make pupils from communicate only in English with the teacher and their classmates according to the comments of respondents. This process must be far away from trying to speak English by just translating language 1 in the classroom. Teacher said that it is very difficult to get their Pupisl learn how use perfect pronunciation. Creese and Blackledge (2010), stated that the first language of pupils could be a basic role in teaching English as just a process of a laguage production. However, it is still the mission of teachers to get the learners aim for native language as much as they can through practice.

\subsection{Discipline}

One Teacher said "disciplines as I am doing my job in our school". Another Teacher said "one of the basic challenges is those pupils who lack discipline itself". As seen above, the discipline doesn't get pupils motivated despite several strategies for maintaining. It is done by the teachers in the state of Kuwait. One can say that discipline has to do with several factors including not sharing the pupils' first language, parental attitudes towards discipline and differentiation. 


\subsection{Motivation}

Teachers felt they are responsible for their pupils to get them motivated by expanding a good deal of energy in teaching inside the classroom and activities done by the pupils themselves that are prepared by their teachers. Teachers of English certainly do before and during the class to make sure the lesson are going well.

\subsection{Differentiation}

Many teachers of English are dealing with pupils who may differ in individual needs as well as learning stages. That's because so many pupils are not ready yet to learn another language. They may also have a particular need for some description. Teachers according to their comments clarified that pupils' knowledge of English is different due to private tutorials they may take in their homes. Such an issue may create some sort of a differentiation wall between log achievers and high ones inside the classroom or between poor and rich pupils (Lamb, 2011). However, teachers always mix between low and medium achievers in the classroom and put them all in the basket of weak pupils in regard with the academic achievement as revealed in the following comment "focusing on weak pupils who do not want to learn English". Such a comment gives a complex picture of attitude towards low achievers by teachers who tend to consider this issue as a problematic one.

\subsection{Writing}

Why thing is considered as another basic challenge to teaching English in the state of Kuwait; particularly, for fourth and fifth grades who are supposed to write a full paragraph mainly consisting of four to five sentences on any given topic from the textbook they learn from. However, many pupils learn to write English by using their first language meaning that they simultaneously improving literacy in two languages rather than one language.

Apart from spelling problem, two aspects of writing that teachers of English in Kuwait refered to; they are how to teach pupils to write correctly and how to teach them to write in a creative way. Most pupils as has been observed just tend to copy words and sentences from the whiteboard, fill in gaps, choose the right answer from a, b, c and write control sentences written by the teachers themselves. While a few number of pupils may reflect some sort of creation and innovation such as writing nything from their mnds that may reflect even writing some simple sentences around any specific topic.Therefor, there seem a big gap between public schools and the private ones in which learners can write creatively because of the different curriculum applied in such types of schools in the state of Kuwait that support both creativity and innovation by learners.

\subsection{Grammar}

Teaching grammar is another basic challenge to teaching English in the primary schools in the state of Kuwait. Most comments indicate that young learners begin to feel boring when their teachers teach them grammar such as the difference between simple and past tenses. What is interesting is that the time of the class is not enough to get all pupils understand grammar well beside the large amount of structures they must cover a week in each unit related to their textbooks. Cameron (2001), clarifies that some young learners in primary stages may benefit from grammar when they are given enough time and too much practice.

\subsection{The Size of Class}

According to the comments of teachers of English, class size is the second most necessary factors that may help in development processes of learning and teaching. Crowded classes make teachers and young learners confused since most of them may not get specific points that they have to be familiar with. So if there is too much noise in the class, more problems may occur and vice versa.

\subsection{Local Challenges}

To answer the following question: "What challenges are witnessed by teachers of English locally in the state of Kuwait?", several similarities and differences were examined among the targeted educational areas in Kuwait as shown in the following table:

Table-1. Outcomes of ranking questions by educational areas available in the state of Kuwa

\begin{tabular}{l|l|l|l|l|l}
\hline Factors Al Asema & $\begin{array}{l}\text { Al Farwaniya } \\
\text { Educational } \\
\text { Area }\end{array}$ & $\begin{array}{l}\text { Al Jahra } \\
\text { Educational } \\
\text { Area }\end{array}$ & $\begin{array}{l}\text { Al Ahmadi } \\
\text { Educational } \\
\text { Area }\end{array}$ & $\begin{array}{l}\text { Mubarak } \\
\text { Khabir } \\
\text { Educational Area } \\
\text { Area }\end{array}$ \\
\hline $\begin{array}{l}\text { Learning and teaching in } \\
\text { new methods }\end{array}$ & 3 & 3 & 5 & 1 & 3 \\
\hline Small size of class to new & 7 & 4 & 7 & 2 & 5 \\
\hline $\begin{array}{l}\text { More access to } \\
\text { technologies and resources }\end{array}$ & 6 & 5 & 7 & 6 & 5 \\
\hline $\begin{array}{l}\text { Enough hours of teaching } \\
\text { English }\end{array}$ & 6 & 8 & 4 & 4 \\
\hline $\begin{array}{l}\text { Developing teachers' level } \\
\text { of English }\end{array}$ & 2 & 8 & 3 & 3 \\
\hline $\begin{array}{l}\text { Teaching English from } \\
\text { earlier stages }\end{array}$ & 2 & 7 & 2 & 6 \\
\hline Less exams/ tests & 8 & 5 & 5 \\
\hline
\end{tabular}


Teachers of English in all 5 educational areas in Kuwait indicated that less exams and tests may help in developing teaching and learning more than other factors. Learning and teaching in in new methods was also little bit compatible. Most educational areas put this factor as the first or second necessary one among the rest of other factors. Better and more access to technologies by so many teachers in the targeted educational areas were ranked to the local challenge. More salient diversity was clear in teachers' attitude towards enough hours of teaching English. Teaching English from earlier stage can be characterized. Al Ahmadi, Mubarak Al Kabeer and Al Jahra educational areas tend to follow the usual trend except $\mathrm{Al}$ Asema educational area that was ranked as the first one.

The small class size indicated considerable variation among the five educational areas. In Al Jahra educational area in which most classes were little bit small, it was ranked first. The rest of educational areas were generally large. Development in English level was ranked fifth. Many teachers of English language; according to several recent reports made by the International Bank have limited English skills since all teachers in Kuwait are from one nationality which is Egypt, but still they are required to teach at any cost because of the lack of teachers of English in the state of Kuwait per year. Overall, these results indicate that challenges teachers of English face are sll common and myriad; but still they can be met not just in Kuwait but around the world.

\section{Conclusion}

This research paper focused on a group of issues in teaching English in primary stage in the state of Kuwait. It has been obvious the teachers of English are challenged by several factors including lack of training, resources and acknowledge. Most teachers suffered from lack of time to teach; particularly, teaching writing and grammar. If there is enough time to teach, it will help teachers of English so much inside the classroom and vice versa. Another challenge that can be made is differentiation. Teachers can be trained to handle such a challenge very well; particularly, those teachers who do not have a good experience in teaching and learning methodologies. Moreover, class size is considered as a more local challenge in all educational areas available in the state of Kuwait; therefore, local educational condition strategies are to mediate such a challenge as possible as they can Matsuda (2006).

Plausibility has to be bulit for teachers of English in order to develop their knowledge and skills to handle all such mentioned challenges to teach effectively young learners. Such a sense has to go along with developing pedagogic knowledge that has to be also the aim of any teacher of English (Kumaravadivelu, 2001).

\section{References}

Ahn, K. (2011). Learning to teach under curriculum reform: The practicum experience in South Korea. Routledge: New York.

Baker, W. (2008). A critical examination of ELT in Thailand: The role of cultural awareness. RELC Journal, 39(1): 131-46.

Butler, Y. G. (2004). What level of English proficiency do elementary school teachers need to attain to teach EFL? Case studies from Korea, Taiwan, and Japan. TESOL Quarterly, 38(2): 245- 64.

Cameron, L. (2001). Teaching languages to young learners. Cambridge University Press: Cambridge.

Cameron, L. (2003). Challenges in ELT from the expansion in teaching children. ELT Journal, 57(2): 105-12.

Carless, D. (2004). Issues in teachers' reinterpretation of a task-based innovation in primary schools. TESOL Quarterly, 38(4): 639-62.

Coleman, H. (2011). Dreams and realities: Developing countries and the english language. The British Council: London.

Creese, A. and Blackledge, A. (2010). Translanguaging in the bilingual classroom: A pedagogy for learning and teaching? The Modern Language Journal, 94(1): 103-15.

Hoque, S. (2009). Teaching english in primary schools in Bangladesh: Competencies and achievements. Garnet Education: NewYork.

$\mathrm{Hu}$, Y. (2007). China's foreign language policy on primary english education: What's behind it? Language Policy, 6(1): 359-76.

İnal, D. (2009). The early bird catches the worm: The turkish case. In J. Enever, J. Moon \& U. Raman (eds), young learner english language policy and implementation: International perspectives. Garnet Education: Reading. 71-78.

Johnstone, R. (2009). An early start: What are the key conditions for generalized success? International perspectives, $12(2): 31-41$.

Kuchah, K. (2009). Early bilingualism in Cameroon: Where politics and education meet International Perspectives, 10(3): 87-94.

Kumaravadivelu, B. (2001). Toward a post-method pedagogy. TESOL Quarterly, 35(1): 537-60.

Kumaravadivelu, B. (2011). Language teacher education for a global society: A modular model for knowing, analyzing, recognizing, doing, and seeing. Routledge: Abingdon.

Kunnan, A. J. (2005). Language assessment from a wider context. Routledge: New Jersey.

Lamb, M. (2011). A 'Matthew Effect' in English language education in a developing country context. The British Council: London.

Littlewood, W. (2007). Communicative and task-based language teaching in East Asian classrooms. Language Teaching, 40(3): 243.

Mathew, R. and Pani, S. (2009). Issues in the implementation of teaching English for young learners (TEYL): A case study of two states in India. International perspectives, 13(2): 113-20. 
Matsuda, A. (2006). Negotiating ELT assumptions in EIL classrooms.InEdge. Palgrave Macmillan: Basingstoke. Mee, C. Y. (2003). English language teaching in singapore today. English language teaching in east asia today: Changing policies and practices. Eastern Universities Press: Singapore. 351-74.

Nunan, D. (2003). The impact of English as a global language on educational policies and practices in the AsiaPacific region. TESOLQuarterly, 37(4): 589-613.

Pillar, I. and Cho, J. (2013). Neoliberalism as language policy. Language in Society, 42(1): 23-44.

Punch, K. (2016). Developing effective research proposals. SAGE Publication Indai: New Delhi.

Reis, H. T. and Judd, C. M. (2000). Handbook of research methods in social and personality psychology: A toolbox for serious researchers. Cambridge University Press: Cambridge.

\section{Appendixes}

\section{The survey sheet}

According to your own experience, rank the following factors that you think would most develop teaching English language to elementary pupils in the state of Kuwait:

Smaller classes

More hours for English classes a week

Development in own level of English as teacher

Fewer tests / evluations sheets

Traning in new methodologies of teaching English

Better access to new technologies in teaching English

Changing the curriculum / textbook

Starting English in an earlier stage

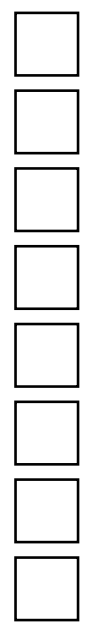

What challenges are experienced locally in the five educational areas available in the state of Kuwait?

\begin{tabular}{|c|c|c|c|c|c|}
\hline Factors & $\begin{array}{l}\text { Al Asema } \\
\text { Educational } \\
\text { Area } \\
\end{array}$ & $\begin{array}{l}\text { Al Jahra } \\
\text { Educational } \\
\text { Area } \\
\end{array}$ & $\begin{array}{l}\text { Mubarak Al- } \\
\text { Khabir } \\
\text { Educational Area } \\
\end{array}$ & $\begin{array}{l}\text { Halli } \\
\text { Educational } \\
\text { Area } \\
\end{array}$ & $\begin{array}{l}\text { Al Farwaniya } \\
\text { Educational } \\
\text { Area } \\
\end{array}$ \\
\hline \multicolumn{6}{|l|}{ Smaller classes } \\
\hline \multicolumn{6}{|l|}{$\begin{array}{l}\text { More hous for English } \\
\text { classes a week }\end{array}$} \\
\hline \multicolumn{6}{|l|}{$\begin{array}{l}\text { Development in own } \\
\text { leverl of English a } \\
\text { teacher }\end{array}$} \\
\hline \multicolumn{6}{|l|}{$\begin{array}{l}\text { Fewer tests } \\
\text { evluations sheets } \\
\text { Traning in new } \\
\text { methodologies of } \\
\text { teaching English }\end{array}$} \\
\hline \multicolumn{6}{|l|}{$\begin{array}{ll}\text { Better access to new } \\
\text { technologies } & \text { in } \\
\text { teaching English } & \\
\end{array}$} \\
\hline \multicolumn{6}{|l|}{$\begin{array}{l}\text { Changing the } \\
\text { curriculum / textbook }\end{array}$} \\
\hline $\begin{array}{l}\text { Starting English in an } \\
\text { earlier stage }\end{array}$ & & & & & \\
\hline
\end{tabular}




\section{The Interview Sheet (An open Question):}

Which aspect do you think the most challenging in teaching young pupils and why? (Further factors are supposed to be given such as motivation, discipline, skills of English, etc.

\section{Ethical Considerations}

\begin{tabular}{|c|c|}
\hline & Please Tick \\
\hline All participants in my research will be adults over the age of 18 & $\sqrt{ }$ \\
\hline All participants in my research will be non-vulnerable adults & $\sqrt{ }$ \\
\hline I will aim to have approximately 20 participants & $\sqrt{ }$ \\
\hline My research will not involve any sensitive topics & $\sqrt{ }$ \\
\hline $\begin{array}{l}\text { I understand the principle of entirely voluntary and fully informed consent and will ensure } \\
\text { my participants do as well }\end{array}$ & $\sqrt{ }$ \\
\hline All participants in my research will receive a research participant information sheet & $\sqrt{ }$ \\
\hline $\begin{array}{l}\text { I will ensure all participants in my research fully understand the research participant } \\
\text { information sheet }\end{array}$ & $\sqrt{ }$ \\
\hline $\begin{array}{l}\text { I will secure the signature of those consenting to participate in my research on the research } \\
\text { participant consent form }\end{array}$ & $\sqrt{ }$ \\
\hline $\begin{array}{l}\text { I will ensure all participants in my research fully understand the consent form and what } \\
\text { they are consenting to before they sign form }\end{array}$ & $\sqrt{ }$ \\
\hline I have appended the research participant information sheet with this proposal & $\sqrt{ }$ \\
\hline I have appended the participant consent form with this proposal & $\sqrt{ }$ \\
\hline $\begin{array}{l}\text { I understand that participant identities must be kept strictly confidential and I will not } \\
\text { reveal them or allow them to be uncovered in my research project or my research } \\
\text { presentation }\end{array}$ & $\sqrt{ }$ \\
\hline $\begin{array}{l}\text { I understand that participant identities and their personal data must be kept securely and } \\
\text { strictly confidential in accordance with the Data Protection Act at all stages of my } \\
\text { research* }\end{array}$ & $\sqrt{ }$ \\
\hline $\begin{array}{l}\text { I understand that I should not put myself or my research participants at risk. I understand } \\
\text { that I should not collect data after dark or outside normal working hours, that interviews } \\
\text { should be conducted in public places on campus and not in private homes, and that I } \\
\text { should not expose myself or my participants to dangerous environments. }\end{array}$ & $\sqrt{ }$ \\
\hline
\end{tabular}

